O R I G I N A L

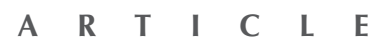

\title{
Anaemia and type 2 diabetes: implications from a retrospectively studied primary care case series
}

\section{Catherine XR Chen 陳曉瑞 \\ YC Li 李燕珠 \\ SL Chan 陳仕鑾 \\ KH Chan 陳景康}

Key words

Anemia; Diabetes mellitus; Primary health care

Hong Kong Med J 2013;19:214-21 DOI: $10.12809 / \mathrm{hkmj} 133814$

Department of Family Medicine and GOPC, Queen Elizabeth Hospital, Jordan, Kowloon, Hong Kong

CXR Chen, PhD, FHKAM (Family Medicine)

YC Li, FRACGP, FHKAM (Family Medicine SL Chan, FRACGP, FHKAM (Family Medicine) KH Chan, FRACGP, FHKAM (Family Medicine)
Objectives To identify the prevalence of anaemia in Chinese type 2 diabetic patients managed in a primary care setting and to explore its associations with cardiovascular complications and kidney disease.

Design Retrospective case series study.

Setting General Out-patient Clinic of Hospital Authority, Hong Kong.

Patients Chinese type 2 diabetic patients who had annual assessments between 1 January 2010 and 31 December 2011 were recruited. Their complete blood picture, serum creatinine, estimated glomerular filtration rate (calculated by Modification of Diet in Renal Disease method), haemoglobin A1c, and urine albumincreatinine ratio were retrieved. Anaemia was defined as a haemoglobin level of $<130 \mathrm{~g} / \mathrm{L}$ in men and $<120 \mathrm{~g} / \mathrm{L}$ in women (World Health Organization criteria). Student's $t$ test and analysis of variance were used to analyse continuous variables and the Chi squared test for categorical data. Pearson's correlation coefficient and multivariate logistic regression were used to examine associations between haemoglobin level and different variables including age, gender, serum creatinine level, estimated glomerular filtration rate, and urine albumin-creatinine ratio. All statistical tests were two-sided, and a $P$ value of $<0.05$ was considered significant.

Results Among 6325 Chinese type 2 diabetic patients fulfilling the inclusion criteria, 1441 were found to have anaemia with a period prevalence of $22.8 \%$. The prevalence of anaemia increased significantly with deterioration of renal function. Compared with diabetic patients with normal haemoglobin levels, anaemic diabetic patients had a higher co-morbidity rate for stroke, ischaemic heart disease, hypertension, and chronic kidney disease $(\mathrm{P}<\mathbf{0 . 0 0 1})$. Independent predictors for haemoglobin level among diabetic patients were age, gender, serum creatinine level, estimated glomerular filtration rate, haemoglobin A1c, and urine albumin-creatinine ratio $(\mathrm{P}<\mathbf{0 . 0 0 1})$. Multivariate analysis showed that male gender, old age, increased serum creatinine level, decreased estimated glomerular filtration rate, elevated urine albumin-creatinine ratio, and co-morbidity with stroke or ischaemic heart disease were associated with greater odds for the presence of anaemia.

Conclusion Anaemia is common among Chinese type 2 diabetic patients, particularly those with impaired renal function or established cardiovascular disease. Early detection of anaemia and prompt referral to specialist care for optimal treatment, if associated with severe renal impairment or high-risk proteinuria at the primary care settings, is recommended. 


\section{Introduction}

Type 2 diabetes mellitus is one of the most common chronic conditions encountered in primary care, and affects up to $10 \%$ of the Hong Kong population. ${ }^{1}$ It is also a leading cause of morbidity and mortality due to complications, including kidney disease, blindness, lower limb amputation, and coronary heart disease. ${ }^{2}$ Its increasing prevalence has placed greater demands on health care systems and carers.

Anaemia is a common concomitant condition among such patients, with a prevalence that varies in different ethnic groups, ranging from $20 \%$ in tertiary referral clinics in Australia, ${ }^{3}$ and up to $45 \%$ in Caribbean type 2 diabetic patients. ${ }^{4}$ The greatest decrease in haemoglobin $(\mathrm{Hb})$ levels was noted in patients with macroalbuminuria and renal impairment. Indeed, anaemia is a well-known complication of chronic kidney disease (CKD) and is now recognised as an early component of diabetic nephropathy. ${ }^{5}$ In addition, chronic anaemia is also regarded as a risk factor for cardiovascular disease (CVD) outcomes in diabetes. ${ }^{6}$

Locally, a significant proportion of type 2 diabetic patients are managed in primary care and followed up at government General Out-patient Clinics (GOPCs) of the Hospital Authority. A group of endocrinologists from The Chinese University of Hong Kong had examined the association between haematocrit and cardiovascular events in a cohort of Chinese type 2 diabetic patients followed up in their specialist out-patient setting. ${ }^{7}$ They found that low levels of haematocrit and the presence of CKD were associated with an increased risk of adverse cardiovascular events. However, local data on the prevalence of anaemia and its clinical significance in Chinese type 2 diabetic patients managed in primary care are still lacking. The clinic where the authors are working is one of the biggest GOPCs of the Hong Kong Hospital Authority; more than $70 \%$ of patients attending the clinic have chronic diseases including

\section{賓血與二型糖尿病：來自基層醫護回顧性病例 系列研究的啟示}

目的 檢視在基層醫護診所覆診的二型糖尿病華人患者其貧 血症的患病率, 並探討其與心血管併發症和腎病的相 關性。

設計 回顧性病例系列研究。

安排 香港醫院管理局轄下一所普通科診所。

患者 於 2010 年 1 月 1 日至 2011 年 12 月 31 日期間在本診所曾 進行糖尿病併發症及風險評估的華人二型糖尿病患者 被納入研究, 並對他們的血常規、血清肌酐、腎小球 濾過率、糖化血紅蛋白（HbAlc）以及尿白蛋白肌酐 比進行分析。根據世界衛生組織標準, 貧血的診斷標 準為男性的血紅蛋白水平 $<130 \mathrm{~g} / \mathrm{L}$ ，女性的血紅蛋白 水平 $<120 \mathrm{~g} / \mathrm{L} \circ t$ 檢驗和方差分析用來分析計量資料, 卡方檢驗用來分析計數資料。皮爾森相關系數和多因 素迴歸分析則用於檢視血紅蛋白與年齡、性別、血清 肌酐、腎小球濾過率和尿白蛋白肌酐比等不同變量間 的關係。所有統計學測試都是雙邊檢定， $\mathrm{P}<0.05$ 表示 數據有統計學顯著性差異。

結果 在符合標準的6325名華人二型糖尿病患者中, 1441 名患有貧血症, 其患病率為 $22.8 \%$ 。貧血症的患病 率與腎功能惡化顯著相關。與正常血紅蛋白的糖尿 病患者相比, 患貧血症的糖尿病患者有較高的共病 率, 包括中風、缺血性心臟病、高血壓和慢性腎病 $(\mathrm{P}<0.001)$ 。糖尿病患者出現血紅蛋白的獨立預測 因子包括年齡、性別、血清肌酐水平、腎小球濾過 率、HbAlc及尿白蛋白肌酐比 $(\mathrm{P}<0.001)$ 。多因素 迴歸分析顯示男性、老年、血清肌酐水平上升、腎小 球濾過率下降、尿白蛋白肌酐比上升，以及併發中風 或缺血性心臟病會增加糖尿病患者患貧血症的機會。

結論 華人二型糖尿病患者中併發貧血十分常見, 並以腎功 能受損或患有心血管疾病者為甚。若二型糖尿病患者 於基層醫護中發現併發有嚴重腎功能受損或高風險蛋 白尿, 應及時作貧血症檢測及轉介至專科, 以便作出 最佳治療。

- Anaemia is common in Chinese type 2 diabetic patients managed in primary care; 1 in 4 such patients will have anaemia.

- The prevalence of anaemia increased significantly with deterioration of renal function; $54 \%$ of such patients had anaemia if they had chronic kidney disease (estimated glomerular filtration rate [eGFR] of $<60 \mathrm{~mL} / \mathrm{min} / 1.73 \mathrm{~m}^{2}$ ).

- Compared with diabetic patients with normal haemoglobin values, those who were anaemic had a higher co-morbidity rate for stroke, ischaemic heart disease (IHD), hypertension, and chronic kidney disease.

- Among these patients, male gender, old age, increased serum creatinine level, decreased eGFR, elevated urine albumin-creatinine ratio, and co-morbidity due to stroke or IHD were all associated with greater odds for the presence of anaemia.

- The high prevalence of anaemia among Chinese type 2 diabetic patients should alert family physicians to the importance of routine screening and regular monitoring for anaemia for such patients, including those without overt nephropathy.

- Early detection of anaemia and prompt referral to specialist care for optimal treatment, if associated with severe renal impairment or high-risk proteinuria in the primary care settings, may help reduce future cardiovascular events and hospital admissions, and improve their well-being and quality of life. 
diabetes. To address this knowledge gap, we set out to identify the prevalence of anaemia among Chinese type 2 diabetic patients in the primary care setting and explore its associations with cardiovascular complications and kidney disease.

\section{Methods}

\section{Study design}

This was a retrospective case series study of Chinese type 2 diabetic patients regularly followed up at the Yau Ma Tei GOPC of the Kowloon Central Cluster.

\section{Subjects}

All Chinese type 2 diabetic patients having the International Classification of Primary Care (ICPC) code T90, who had been regularly followed up in this clinic between 1 January 2010 and 31 December 2011, and had annual blood and urine checkups at least once during that period were recruited. The diagnosis of diabetes was based on the "Definition and description of diabetes mellitus" from American Diabetes Association in $2010 .^{8}$ In this clinic, diabetic patients were usually provided with blood and urine checkups at least annually to every 18 months. This 2-year retrieval period was therefore likely to cover all such patients regularly followed up in this clinic. Wrongly diagnosed diabetic patients, type 1 diabetic patients, diabetic patients who were not Chinese, and patients who had not had an annual checkup within this period were excluded.

\section{Definition of anaemia}

According to the World Health Organization (WHO) gender-specific criteria, ${ }^{9}$ anaemia in this study was defined as a $\mathrm{Hb}$ level of $<130 \mathrm{~g} / \mathrm{L}$ in men and $<120 \mathrm{~g} / \mathrm{L}$ in women. Anaemia was defined as normocytic with a mean corpuscular volume (MCV) of 80 to $100 \mathrm{fL}$, microcytic if the MCV was $<80 \mathrm{fL}$, and macrocytic if the MCV was $>100 \mathrm{fL}$.

\section{Determination of variables}

Each recruited patient's age, gender, smoking status, body mass index (BMI), complete blood picture reports, serum creatinine $(\mathrm{Cr})$ and blood haemoglobin A1c (HbA1c) levels, as well as urine albumin-creatinine ratio (ACR) were retrieved from the Clinical Management System (CMS) of the Hospital Authority. The most recent blood test that included a complete blood picture was used for analysis if more than one test had been performed during the study period. The BMI was calculated as body weight $(\mathrm{kg}) /$ body weight ${ }^{2}\left(\mathrm{~m}^{2}\right)$. The patient was considered a smoker if he/she currently smoked or was within the first 6 months of quitting.
The Modification of Diet in Renal Disease method was used to measure the estimated glomerular filtration rate (eGFR), expressed as $\mathrm{mL} / \mathrm{min} / 1.73 \mathrm{~m}^{2}$, in which

eGFR =

$186 \times(\mathrm{SCR} \times 0.011)^{-1.154} \times(\text { age })^{-0.203} \times(0.742$ [if female] $) \times 1.233$

where SCR is the serum $\mathrm{Cr}$ expressed as $\mu \mathrm{mol} / \mathrm{L}^{10}$

Chronic kidney disease was defined as having an eGFR of $<60 \mathrm{~mL} / \mathrm{min} / 1.73 \mathrm{~m}^{2}$.

Microalbuminuria was defined as albumin secretion of 30 to $300 \mathrm{mg} / 24 \mathrm{~h}$ and macroalbuminuria or proteinuria as a value of $>300 \mathrm{mg} / 24 \mathrm{~h}$. According to the American Diabetes Association guideline, ${ }^{11}$ screening for microalbuminuria can be performed by measurement of urine ACR in a random spot collection. As suggested by the Scottish Intercollegiate Guidelines Network on the management of diabetes (March 2010), normoalbuminuria was defined as a urine ACR of $<2.5 \mathrm{mg} / \mathrm{mmol}$ in males and $<3.5$ $\mathrm{mg} / \mathrm{mmol}$ in females. ${ }^{12}$ Corresponding values for microalbuminuria were defined as 2.5 to $30 \mathrm{mg} / \mathrm{mmol}$ for males and 3.5 to $30 \mathrm{mg} / \mathrm{mmol}$ for females, and for macroalbuminuria they were $>30 \mathrm{mg} / \mathrm{mmol}$ for both sexes. ${ }^{12}$ An elevated urine ACR needed to be confirmed in the absence of urinary tract infection with additional first-void specimens collected during the next 3 to 6 months. Due to the high associated risk, patients with urine ACRs of $\geq 150 \mathrm{mg} / \mathrm{mmol}$ were considered a separate group.

A medical history of stroke, ischaemic heart disease (IHD), and concomitant hypertension (HT) were retrieved using the ICPC code from the CMS. For stroke cases, the ICPC codes were K89 (transient ischaemic attack), K90 (cerebrovascular accident), and $\mathrm{K} 91$ (cerebrovascular disease). The HT ICPC codes were K86 (uncomplicated) and K87 (complicated), whereas the IHD ICPC codes were K74 (IHD with angina), K75 (acute myocardial infarction), and K76 (IHD without angina). Repeat systolic blood pressures of $\geq 130 \mathrm{~mm} \mathrm{Hg}$ or diastolic blood pressures of $\geq 80 \mathrm{~mm} \mathrm{Hg}$ confirmed a diagnosis of HT in diabetic patients. ${ }^{13}$

\section{Statistical analysis}

All data were entered and analysed using computer software (Windows version 16.0; SPSS Inc, Chicago [IL], US). Student's $t$ test and analysis of variance were used for analysing continuous variables and the Chi squared test for categorical data. Pearson's correlation and multivariate logistic regression were used to determine the association between $\mathrm{Hb}$ levels and different variables including age, gender, serum $\mathrm{Cr}$, eGFR, urine ACR, and co-morbidities such as stroke, IHD, or HT. All statistical tests were twosided, and a $\mathrm{P}$ value of less than 0.05 was considered significant. 
TABLE I. Demographic characteristics of diabetic patients with or without anaemia

\begin{tabular}{|c|c|c|c|}
\hline \multirow[t]{2}{*}{ Demographic } & \multicolumn{2}{|c|}{ No. $(\%)$ of patients or mean \pm standard deviation } & \multirow[t]{2}{*}{$P$ value } \\
\hline & Without anaemia $(n=4884)$ & With anaemia $(n=1441)$ & \\
\hline \multicolumn{4}{|l|}{ Gender } \\
\hline Male & $2630(54 \%)$ & $757(53 \%)$ & 0.38 \\
\hline Female & $2254(46 \%)$ & $684(47 \%)$ & \\
\hline Male-to-female ratio & $1: 1.17$ & $1: 1.11$ & \\
\hline Mean age (years) & $62.9 \pm 11.6$ & $70.9 \pm 11.4$ & $<0.001$ \\
\hline Smoker & $920(19 \%)$ & $298(21 \%)$ & 0.13 \\
\hline Mean body mass index $\left(\mathrm{kg} / \mathrm{m}^{2}\right)$ & $27.7 \pm 4.5$ & $27.3 \pm 2.3$ & 0.53 \\
\hline
\end{tabular}

TABLE 2. Metabolic control, kidney function, and concomitant disease of diabetic patients with or without anaemia*

\begin{tabular}{|c|c|c|c|}
\hline Item & Without anaemia $(n=4884)$ & With anaemia $(n=1441)$ & $P$ value \\
\hline Haemoglobin A1c (\%) & $7.4 \pm 1.4$ & $7.3 \pm 1.4$ & 0.003 \\
\hline Serum creatinine $(\mu \mathrm{mol} / \mathrm{L})$ & $78.1 \pm 21.6$ & $102.9 \pm 60.8$ & $<0.001$ \\
\hline Estimated glomerular filtration rate (eGFR) $\left[\mathrm{mL} / \mathrm{min} / 1.73 \mathrm{~m}^{2}\right]$ & $86.9 \pm 33.7$ & $69.7 \pm 27.1$ & $<0.001$ \\
\hline Urine albumin-creatinine ratio $(\mathrm{mg} / \mathrm{mmol})$ & $4.79 \pm 22.5$ & $14.2 \pm 63.5$ & $<0.001$ \\
\hline Normoalbuminuria & $3904(80 \%)$ & $945(66 \%)$ & $<0.001$ \\
\hline Microalbuminuria & $817(17 \%)$ & $349(24 \%)$ & $<0.001$ \\
\hline Macroalbuminuria & $113(2 \%)$ & $70(5 \%)$ & $<0.001$ \\
\hline High-risk proteinuria & $50(1 \%)$ & $77(5 \%)$ & $<0.001$ \\
\hline \multicolumn{4}{|l|}{ Concomitant disease } \\
\hline Stroke & $282(6 \%)$ & $163(11 \%)$ & $<0.001$ \\
\hline Ischaemic heart disease & $195(4 \%)$ & $96(7 \%)$ & $<0.001$ \\
\hline Hypertension & 3645 (75\%) & $1182(82 \%)$ & $<0.001$ \\
\hline Chronic kidney disease (ie eGFR $<60 \mathrm{~mL} / \mathrm{min} / 1.73 \mathrm{~m}^{2}$ ) & $446(9 \%)$ & $523(36 \%)$ & $<0.001$ \\
\hline
\end{tabular}

* Data are shown as mean \pm standard deviation or No. (\%) of cases

\section{Results}

A total of 7481 type 2 diabetic patients followed up in our clinic between 1 January 2010 and 31 December 2011 was generated from the CMS. Among them, 1156 (16\%) patients were excluded based on the exclusion criteria. These patients included 5 wrongly diagnosed as diabetic, 1 with type 1 diabetes, 499 who were not Chinese, and 651 who had not had their blood and urine checked during the recruitment period. Thus, 6325 patients fulfilling the inclusion criteria were recruited into this study.

Among these recruits, 1441 patients were found to have anaemia during the study period, giving a period prevalence of $22.8 \%$. Table 1 summarises the demographic characteristics of these diabetic patients with or without anaemia. In summary, they were comparable in terms of male-to-female ratio, smoking status, and BMI (all $\mathrm{P}>0.05$ ). However, the anaemic group was significantly older, the mean \pm standard deviation (SD) age being $70.9 \pm 11.4$ years (vs non-anaemic group, $62.9 \pm 11.6$ years; $\mathrm{P}<0.001$ ).

\section{Pattern of anaemia in anaemic diabetic patients}

Among the 1441 diabetic patients who were anaemic (as defined by gender-specific WHO criteria), more than half had a normocytic $(n=879,61 \%)$ type, whilst fewer were microcytic $(n=392,27 \%)$ or macrocytic $(n=170,12 \%)$. Among those with microcytic anaemia and iron profile or $\mathrm{Hb}$ pattern checked $(\mathrm{n}=335)$, 76 had iron deficiency and 32 (23 females and 9 males) had thalassaemia minor. Among those with macrocytic anaemia who had their serum vitamin B12 level checked ( $n=106), 46$ had vitamin B12 deficiency.

Table 2 summarises the glycaemic control, kidney function, and presence of concomitant diseases in these diabetic patients with or without anaemia. Diabetic patients with normal $\mathrm{Hb}$ levels had a significantly higher mean $( \pm$ SD) HbA1c level than those who were anaemic $(7.4 \pm 1.4 \%$ vs 7.3 $\pm 1.4 \% ; \mathrm{P}=0.003$ ). With regard to kidney function, mean serum $\mathrm{Cr}$ level of the anaemic groups was significantly higher than that of the non-anaemic patients, with a mean eGFR that was significantly 
lower than that in the latter group. In addition, among diabetic patients with and without anaemia, the proportions suffering from microalbuminuria, macroalbuminuria, and high-risk proteinuria were invariably higher in the anaemic group (all $\mathrm{P}<0.001$ ). When co-morbidity due to cardiovascular and CKD was compared, they too were more common in the anaemic than non-anaemic diabetic patients. The corresponding proportions were $11 \%$ versus $6 \%$ for stroke, $7 \%$ versus $4 \%$ for IHD, $82 \%$ versus $75 \%$ for $\mathrm{HT}$ and $36 \%$ versus $9 \%$ for $\mathrm{CKD}$ (all $\mathrm{P}<0.001$ ).

Figure 1 describes the association between $\mathrm{Hb}$ level and declining eGFR in patients with diabetes. Stratifications by gender revealed parallel trends in both sexes. For all subgroups, the $\mathrm{Hb}$ was significantly lower in patients with eGFR values of

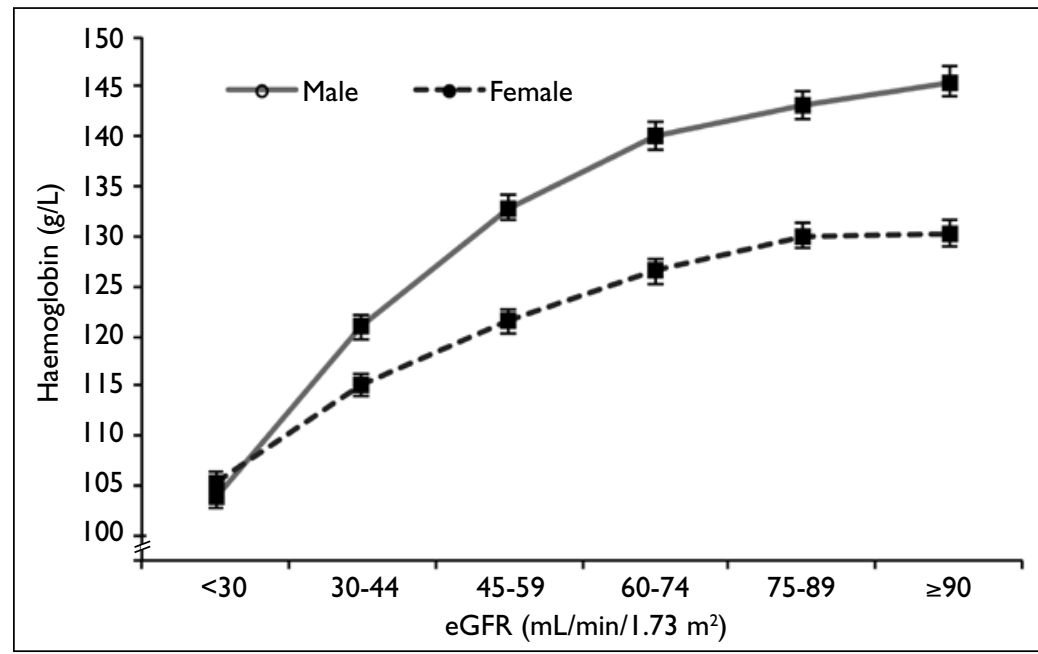

FIG I. The association between haemoglobin and estimated glomerular filtration rate (eGFR) in patients with diabetes

Compared with the group of eGFR $>90 \mathrm{~mL} / \mathrm{min} / 1.73 \mathrm{~m}^{2}$, the $P$ values within male and female subgroups were all $<0.005$

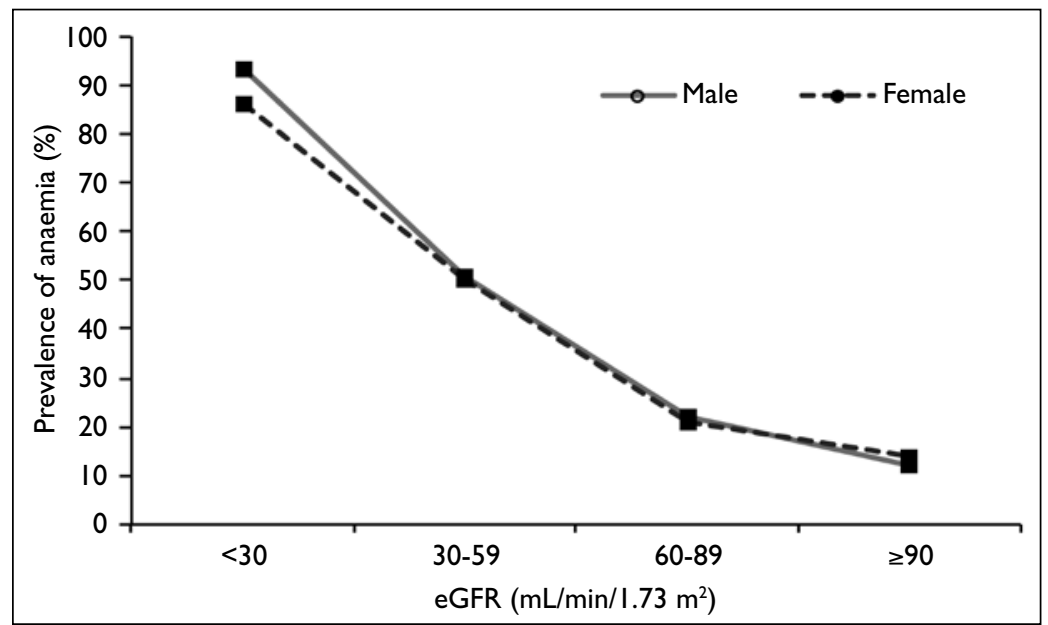

FIG 2. The prevalence of anaemia in patients with diabetes stratified according to estimated glomerular filtration rate (eGFR)

Compared with the group of eGFR $>90 \mathrm{~mL} / \mathrm{min} / 1.73 \mathrm{~m}^{2}$, the $P$ values within male and female subgroups were all $<0.00$ I
$<90 \mathrm{~mL} / \mathrm{min} / 1.73 \mathrm{~m}^{2}$ than those with higher values.

Figure 2 describes the prevalence of anaemia in patients with diabetes according to eGFR. Stratification by gender revealed parallel trends in both sexes. The prevalence increased significantly with deterioration of renal function. Thus, $93 \%$ of male and $86 \%$ of female patients with eGFRs of $<30$ $\mathrm{mL} / \mathrm{min} / 1.73 \mathrm{~m}^{2}$ were anaemic, while the respective proportions for males and females were $51 \%$ and $50 \%$ for those with eGFRs of 30 to $59 \mathrm{~mL} / \mathrm{min} / 1.73 \mathrm{~m}^{2}$, and $22 \%$ and $21 \%$ for those with eGFRs of 60 to $89 \mathrm{~mL} /$ $\min / 1.73 \mathrm{~m}^{2}$. The corresponding proportions were all significantly higher $(\mathrm{P}<0.001)$ than those with eGFRs of $>90 \mathrm{~mL} / \mathrm{min} / 1.73 \mathrm{~m}^{2}$ (12\% of male and $14 \%$ female).

\section{Predictors of haemoglobin level}

In this cohort of Chinese diabetic patients, the mean $( \pm$ SD) Hb level was $139 \pm 16 \mathrm{~g} / \mathrm{L}$ for males and 128 $\pm 13 \mathrm{~g} / \mathrm{L}$ for females $(\mathrm{P}<0.01)$. Pearson's correlation analysis showed that independent predictors for $\mathrm{Hb}$ among these diabetic patients were age $(r=-0.34)$, gender (males had significantly higher $\mathrm{Hb}$ levels), serum $\mathrm{Cr}(r=-0.22)$, eGFR $(r=0.30), \mathrm{HbA1c}(r=0.06)$, and urine ACR $(r=-0.12)$ [all $\mathrm{P}<0.001$; Table 3]. When the $\mathrm{Hb}$ level was dichotomised as anaemia and nonanaemia and the data were submitted to multivariate logistic regression analyses, the results showed that male gender, older age, increased serum $\mathrm{Cr}$, reduced eGFR, elevated urine ACR, and co-morbidity with stroke or IHD were all associated with greater odds for the presence of anaemia (Table 4), while HbA1c and concomitant HT had no association with the anaemic status.

\section{Discussion}

We believe this locally conducted study, which described the prevalence of anaemia and its predictors in Chinese diabetic patients managed in primary care, is the largest clinical analysis of anaemic conditions among Chinese type 2 diabetic patients to date.

Both locally and worldwide, anaemia is a common concern in geriatric health but its exact prevalence remains unclear. Several studies have addressed this issue with discrepant results. Locally, one study reported the prevalence of anaemia among Chinese geriatric subjects (defined as those aged $>60$ years) and found it to be $6.4 \%$ and $6.3 \%$ respectively among men and women with co-morbidity including haemoglobinopathies. ${ }^{14}$ Our study revealed that anaemia was commonly present in Chinese diabetic patients managed in local primary care facilities, with a period prevalence of up to $23 \%$. This is much higher than that in the general geriatric population and may represent a significant unrecognised burden. This prevalence is comparable to that reported in diabetic patients in Australia, ${ }^{5}$ but was much lower than 
TABLE 3. Pearson's correlations between haemoglobin levels with patient's age, haemoglobin $A I c(H b A I c)$, serum creatinine, estimated glomerular filtration rate (eGFR), and urine albumin-creatinine ratio (ACR)

\begin{tabular}{lcccccc}
\hline Item & Haemoglobin & Age & HbA1c & Creatinine & eGFR & Urine ACR \\
\hline Pearson's correlation & - & -0.34 & 0.06 & -0.22 & 0.30 & -0.12 \\
P value (2-tailed) & - & $<0.001$ & $<0.001$ & $<0.001$ & $<0.001$ & $<0.001$ \\
No. of cases & 6325 & 6325 & $6293^{*}$ & 6325 & 6325 & 6325 \\
\hline
\end{tabular}

* HbA1c results were not available in 32 diabetic patients with thalassaemia trait or haemoglobinopathy and therefore were excluded from analysis

TABLE 4. Logistic regression between haemoglobin levels with patient's gender, age, haemoglobin Alc (HbAlc), serum creatinine estimated glomerular filtration rate (eGFR), and urine albumin-creatinine ratio (ACR), and presence with stroke, ischaemic heart disease (IHD) or hypertension (HT)

\begin{tabular}{lccc}
\hline Item & P value & $\begin{array}{c}\text { Odds } \\
\text { ratio }\end{array}$ & $\begin{array}{c}\text { 95\% Confidence } \\
\text { interval }\end{array}$ \\
\hline Gender & $<0.001$ & 1.83 & $1.522-2.196$ \\
Age & $<0.001$ & 1.05 & $1.045-1.059$ \\
HbA1c & 0.68 & 0.97 & $0.95-1.054$ \\
Serum creatinine & $<0.001$ & 1.03 & $1.025-1.038$ \\
eGFR & $<0.001$ & 1.01 & $1.006-1.021$ \\
\hline Urine ACR & 0.01 & 1.00 & $1.001-1.005$ \\
Stroke & 0.02 & 1.31 & $1.017-1.642$ \\
IHD & 0.03 & 1.17 & $1.013-1.346$ \\
HT & 0.08 & 0.86 & $0.727-1.019$ \\
\hline
\end{tabular}

that reported in the US $(34.7 \%)^{15}$ and in Caribbeans $(46.5 \%) .{ }^{4}$ The disparity could be partially explained by different degrees of diabetes severity managed in primary and secondary care in these regions. Diabetic patients with stable metabolic control and less severe complications are more likely to be managed in the primary care and therefore have a lower prevalence of anaemia compared with those managed in secondary or tertiary settings. In addition, ethnicity plays a part in the liability to anaemia and might account for some of the observed ethnic disparities. ${ }^{16}$ Anaemia has the potential to adversely affect the health status of diabetic patients in different ways. Studies have shown that patients with anaemia generally have a low quality of life compared with those who are non-anaemic. In addition, their sense of well-being including working and social lives may be adversely affected..$^{17}$

Reasons for anaemia among diabetic patients are multifactorial. Most of our anaemic patients were normocytic $(61 \%)$, whilst fewer were microcytic $(27 \%)$ and macrocytic $(12 \%)$. The most common cause is anaemia due to chronic diseases including $\mathrm{HT}$, IHD, stroke and CKD, and less often they have iron deficiency, thalassaemia minor or vitamin B12 deficiency. However, since this study was carried out in the primary care setting, many patients with anaemia were not worked up, and therefore their underlying pathology remained unknown. Further studies into possible reasons for iron or B12 deficiency in these patients are needed. When patients were stratified according to eGFR, not surprisingly, the prevalence of anaemia increased significantly with deterioration of renal function. Thus, in this study $54 \%$ of diabetic patients with CKD were anaemic, which was significantly higher than those without CKD $(\mathrm{P}<0.001)$. In addition, anaemic diabetic patients were more likely to have concomitant diabetic nephropathy with microalbuminuria, macroalbuminuria, and high-risk proteinuria (Table 2). Impaired renal erythropoietin release in response to declining $\mathrm{Hb}$ levels has been postulated to be the major contributor accounting for the presence of anaemia among such patients. ${ }^{18}$ Other causes include occult blood loss, malnutrition, hyperparathyroidism, systemic inflammation, and reduced red cell survival. ${ }^{19}$ In patients with CKD, the presence of anaemia contributes significantly to morbidity, causing symptoms such as lack of energy, poor appetite, and dizziness. ${ }^{20}$ On the other hand, anaemia was not confined to diabetic patients who had renal impairment; $12.6 \%$ of these diabetic patients had anaemia with what could be called "normal renal function" (eGFR $>90 \mathrm{~mL} / \mathrm{min} / 1.73 \mathrm{~m}^{2}$ ). The presence of anaemia, whatever the cause, helps to identify those at a greater risk for adverse outcomes.

Further studies into the co-morbidity of diabetic patients revealed that a much higher proportion of anaemic diabetics had a history of stroke, IHD, and HT compared with those who were non-anaemic (all $\mathrm{P}<0.001)$. These data suggest that such anaemia might be attributable to the development of cardiovascular complications in diabetic patients, but must be interpreted with caution since age might be an important confounder. In this study, the anaemic diabetic patients were significantly older than those with a normal $\mathrm{Hb}$ level $(70.9 \pm 11.4$ vs $62.9 \pm 11.6$ years; $\mathrm{P}<0.001$ ) [Table 1]. Older age is an established cardiovascular risk factor in all populations besides predisposing to anaemia. ${ }^{21}$ Therefore, future studies need to stratify diabetic patients according to different age-groups, so as to better establish the relationship between anaemia and concomitant CVDs. Nevertheless, studies carried out in the 
general population ${ }^{22}$ as well as in patients with kidney disease $^{23}$ and heart failure ${ }^{24}$ showed that chronic anaemia is an independent risk factor for CVD events. It has been postulated that long-term anaemia might predispose to adverse CVD outcomes, by virtue of ventricular remodelling, cardiac dysfunction, and left ventricular hypertrophy. ${ }^{25}$ Other possibilities included decreased nutritional status and increased inflammation in the presence of chronic anaemia. ${ }^{26}$ Anaemia, CKD, and cardiovascular complications may therefore act together in a vicious circle, in which one condition causes or exacerbates the other.

With regard to predictors of the $\mathrm{Hb}$ level, multivariate logistic regression analyses showed that male gender, old age, increased serum $\mathrm{Cr}$ level, reduced eGFR, elevated urine ACR, and co-morbidity due to stroke or IHD were all associated with greater odds for the presence of anaemia (Table 4). This result was similar with findings from the follow-up of diabetic patients in the specialist clinic in Australia, ${ }^{5}$ and helps us to easily identify diabetic patients that were more likely to have anaemia and therefore in need of early intervention. They also emphasise the importance of checking eGFR in the management of diabetic patients, particularly in the elderly whose apparently "normal renal function" could be related to reduced muscle mass. ${ }^{27}$

\section{Implications for primary care}

Family physicians are at the forefront in the management of type 2 diabetes, and aim to achieve optimal metabolic control to prevent macro- and micro-vascular complications. This study has provided important background information on the high prevalence of anaemia among Chinese type 2 diabetic patients. It also alerts family physicians to the importance of routine screening and regular monitoring for anaemia in primary care, including for patients without overt nephropathy. This is particularly important in busy GOPCs, where haematological tests were not routinely performed as part of the annual assessment. We believe that regular monitoring of the $\mathrm{Hb}$ level in type 2 diabetic patients, together with early detection of anaemia and prompt referral to specialist care if associated with severe renal impairment or high-risk proteinuria at the primary care settings, would help to reduce their cardiovascular events, hospital admissions, and therefore improve their well-being and quality of life.

\section{Limitations of this study}

Firstly, only diabetic patients who had been regularly followed up in this single clinic and who had annual blood and urine checks at least once during this 2-year period were recruited. Those who never attended the annual assessment whatever the reason were excluded. This could have introduced a selection bias. Secondly, all variables were measured at least once during the 2-year study period. When more than one blood test had been performed, the most recent test that included a complete blood count was used for analysis. Therefore, variability of finding may confound the effect of covariates on outcomes. Thirdly, concomitant chronic diseases (HT, IHD, and stroke) were retrieved via the ICPC code in the CMS, so that inadequate coding may underestimate such co-morbidity in both the normal $\mathrm{Hb}$ and anaemia groups. In addition, the duration of diabetes could be an important attributing factor to the presence of anaemia. Regrettably, we had difficulties in compiling these data, since they were not retrievable for diabetic patients due to poor documentations in the CMS, and therefore were not included in this study. Lastly, because of the cross-sectional nature of our study, we were unable to adjust for potential unmeasured confounders and therefore no temporal or causal relationship could be established.

\section{Conclusion}

In summary, anaemia is commonly present among Chinese type 2 diabetic patients, particularly those with impaired renal function, diabetic nephropathy, or CVDs. Therefore, we recommend regular monitoring of the $\mathrm{Hb}$ level among diabetic patients in primary care settings to enable early detection of anaemia and prompt referral to specialist care for optimal treatment. Such a policy appears especially important for patients with severe renal impairment or high-risk proteinuria.

\section{Acknowledgements}

I sincerely thank Dr King Chan for his continuous encouragement, inspiration, and support during this study. I would also like to thank Ms Katherine Chan, statistical officer of Queen Elizabeth Hospital, Kowloon Central Cluster for her expert statistical support and Ms Elise Chan for her great help in the data entry.

\section{References}

1. Chan JC, MalikV, Jia W, et al. Diabetes in Asia: epidemiology, risk factors, and pathophysiology. JAMA 2009;301:212940. cross ref
2. Leung GM, Lam KS. Diabetic complications and their implications on health care in Asia. Hong Kong Med J 2000;6:61-8. 
3. Thomas MC, Tsalamandris C, Maclsaac RJ, Jerums G. The epidemiology of haemoglobin levels in patients with type 2 diabetes. Am J Kidney Dis 2006;48:537-45. cross ref

4. Ezenwaka CE, Jones-Lecointe A, Nwagbara E, Seales D, Okali F. Anaemia and kidney dysfunction in Caribbean Type 2 diabetic patients. Cardiovasc Diabetol 2008;7:25. cross ref

5. McFarlane SI, Salifu MO, Makaryus J, Sowers JR. Anemia and cardiovascular disease in diabetic nephropathy. Curr Diab Rep 2006;6:213-8. cross ref

6. Vlagopoulos PT, Tighiouart H, Weiner DE, et al. Anemia as a risk factor for cardiovascular disease and all-cause mortality in diabetes: the impact of chronic kidney disease. J Am Soc Nephrol 2005;16:3403-10. cross ref

7. Tong PC, Kong AP, So WY, et al. Hematocrit, independent of chronic kidney disease, predicts adverse cardiovascular outcomes in Chinese patients with type 2 diabetes. Diabetes Care 2006;29:2439-44. cross ref

8. American Diabetes Association. Diagnosis and classification of diabetes mellitus. Diabetes Care 2010;33(Suppl 1):S629. cross ref

9. World Health Organization. Worldwide prevalence of anaemia 1993-2005. Geneva, Switzerland: WHO; 2008.

10. Levey AS, Bosch JP, Lewis JB, Greene T, Rogers N, Roth D. A more accurate method to estimate glomerular filtration rate from serum creatinine: a new prediction equation. Modification of Diet in Renal Disease Study Group. Ann Intern Med 1999;130:461-70. cross ref

11. American Diabetes Association. Standards of medical care in diabetes 2011. Diabetes Care 2011;34(Suppl 1):S1161. cross ref

12. Management of diabetes. Scottish Intercollegiate Guidelines Network. Edinburgh: SIGN; 2010.

13. Chobanian AV, Bakris GL, Black HR, et al. Seventh report of the Joint National Committee on prevention, detection, evaluation, and treatment of high blood pressure. Hypertension 2003;42:1206-52. cross ref

14. Woo J, Arumanayagam M, Ho SC, Swaminathan R. Haematological indices and the prevalence of anaemia in an elderly Chinese population. Pathology 1989;21:314. cross ref

15. Ahmed AT, Go AS, Warton EM, Parker MM, Karter AJ. Ethnic differences in anaemia among patients with diabetes mellitus: the Diabetes Study of Northern California
(DISTANCE). Am J Hematol 2010;85:57-61.

16. Karter AJ, Ferrara A, Liu JY, Moffet HH, Ackerson LM, Selby JV. Ethnic disparities in diabetic complications in an insured population. JAMA 2002;287:2519-27. cross ref

17. Denny SD, Kuchibhatla MN, Cohen HJ. Impact of anemia on mortality, cognition, and function in community-dwelling elderly. Am J Med 2006;119:327-34. cross ref

18. Winkler AS, Marsden J, Chaudhuri KR, Hambley H, Watkins PJ. Erythropoietin depletion and anaemia in diabetes mellitus. Diabet Med 1999;16:813-9. cross ref

19. Mehdi U, Toto RD. Anemia, diabetes, and chronic kidney disease. Diabetes Care 2009;32:1320-6. cross ref

20. Sarnak MJ, Tighiouart H, Manjunath G, et al. Anemia as a risk factor for cardiovascular disease in The Atherosclerosis Risk in Communities (ARIC) study. J Am Coll Cardiol 2002;40:27-33. cross ref

21. Eisenstaedt R, Penninx BW, Woodman RC. Anemia in the elderly: current understanding and emerging concepts. Blood Rev 2006;20:213-26. cross ref

22. Jurkovitz CT, Abramson JL, Vaccarino LV, Weintraub WS, McClellan WM. Association of high serum creatinine and anemia increases the risk of coronary events: results from the prospective community-based atherosclerosis risk in communities (ARIC) study. J Am Soc Nephrol 2003;14:291925. cross ref

23. Locatelli F, Covic A, Eckardt KU, Wiecek A, Vanholder R; ERA-EDTA ERBP Advisory Board. Anaemia management in patients with chronic kidney disease: a position statement by the Anaemia Working Group of European Renal Best Practice (ERBP). Nephrol Dial Transplant 2009;24:34854. cross ref

24. Anand I, McMurray JJ, Whitmore J, et al. Anemia and its relationship to clinical outcome in heart failure. Circulation 2004;110:149-54. cross ref

25. Al-Ahmad A, Rand WM, Manjunath G, et al. Reduced kidney function and anaemia as risk factors for mortality in patients with left ventricular dysfunction. J Am Coll Cardiol 2001;38:955-62. cross ref

26. Le Jemtel TH, Arain S. Mediators of anaemia in chronic heart failure. Heart Fail Clin 2010;6:289-93. cross ref

27. Swedko PJ, Clark HD, Paramsothy K, Akbari A. Serum creatinine is an inadequate screening test for renal failure in elderly patients. Arch Intern Med 2003;163:356-60. cross ref 